\title{
The Functional and Three Beauty Theory: An Alternative Perspective on the Chinese Translation of English Advertisement
}

\author{
Lee Pin Ling (Corresponding author) \\ School of Languages, Literacies \& Translation, Universiti Sains Malaysia, Malaysia \\ Tengku Sepora Tengku Mahadi \\ School of Languages, Literacies \& Translation, Universiti Sains Malaysia, Malaysia
}

Received: 11-08-2016

doi:10.7575/aiac.ijclts.v.4n.4p.5
Accepted: 19-09-2016

Published: 31-10-2016

\begin{abstract}
Considering the multiracial, multicultural and multilingual background of the readers in Malaysia, it is very common to find advertisements with exactly the same graphics but in different languages. From the survey of previous studies, it is found that the Chinese translation of English advertisement in Malaysia has not received adequate attention from researchers. Apart from this, it is found that the adoption of the Three Beauty Theory into the translation of advertisement has not captured much attention from researchers. Thus, this study attempts to fill this gap by looking into the Chinese translation of English advertisement in Malaysian newspapers, based on the Functional Translation Theory and the Three Beauty Theory. The result of this study shows that the use of three aspects of Chinese language (meaning, sound and form) in analysing and identifying the appellativeness of a Chinese translated English headline is appropriate. In addition to that, the effectiveness of Chinese translation of English advertisement headline, in terms of meaning, sound and form could be analysed and improved, based on the Three Beauty Theory. In short, the Functional Translation Theories provides a guideline on the purpose of translation, typology, and language function and translation strategy in the Chinese translation of English advertisement. On the other hand, the Three Beauty Theory safeguards the effectiveness and the beauty of Chinese language, in terms of meaning (idea, message), form (structure) and sound (phonology).
\end{abstract}

Keywords: Chinese translation, English advertisement, Functional Translation Theory, Three Beauty Theory

1. Introduction

In a multiracial, multicultural and multilingual country like Malaysia, readers are exposed to advertisements of different languages. In Malaysia, it is not surprising to find an advertisement with exactly the same graphics but in different languages. Advertisements, or more specifically commercial advertisements in Malaysia, are generally written in English, before being translated into other languages, such Malay, Chinese, and Tamil. An effective advertisement is able to attract customers' attention and thus improve the sales of products or services. The translation of advertisement is carried out when the advertisement is targeted at different language readers. Therefore, attention given to advertisement translation, if not more, should not be less than advertisement write-up, as both the original and translated texts of advertisement are playing the same role.

According to Bolen, advertising is "paid, non-personal communication through various mass media by business firms, nonprofit organizations, and individuals who are in some way identified in the message and who hope to inform or persuade members of a particular audience". Bolen (1984: 9). An informative advertisement informs "the customer about goods, services, or ideas and then tells how to get them by means of an identified sponsor". (Bolen 1984: 6). A persuasive advertisement "should try to persuade the potential customers that they need to buy the new product". (Bolen 1984: 6). In short, advertising itself has a very clear objective or function which is "to inform or to persuade". Thus, both original and translated advertisements should have the same purpose and function, and both should be able to achieve the same purpose and function. This paper studies mainly the Chinese translation of Malaysian English advertisement, from the perspective of functional translation theories and Three Beauty Theory.

\section{Theoretical Perspectives and Literature Review}

\subsection{Functional Theory}

According to the Functional Theories of translation, translating is regarded as a "purposeful activity" (Nord, 1997). In 1970, Katharina Reiss introduced a functional category in her "objective approach to translation criticism". According to Reiss, the ideal translation would be one "in which the aim in the TL is equivalence as regards the conceptual content, linguistic form and communicative function of a SL text". (1977, translation in 1989:112). In the 1980s, Hans J. Vermeer developed "Skopos Theory" based on Reiss's functional theory. According to Vermeer, translation is a type of human action, and he defines human action as intentional, purposeful behavior that takes place in any given situation. (1978,1983b:49). Christiane Nord concluded the functional theory suggested by Reiss and Vermeer: the objective to be achieved in translation decides the whole process of translation behavior, as well as translation strategy. 
In regards to the classification of communicative purposes, Reiss (1971) proposed a text typology for translator based on Karl Bühler's (1934) categorization of three basic functions of language. Reiss divided the texts type into three types: informative, expressive and appellative, and stated that specific translation methods should be chosen according to different text types and the function of the texts determined the translation methods (Chen Xi, 2013). The following is Reiss's text type and text varieties (Munday, 2010:74).

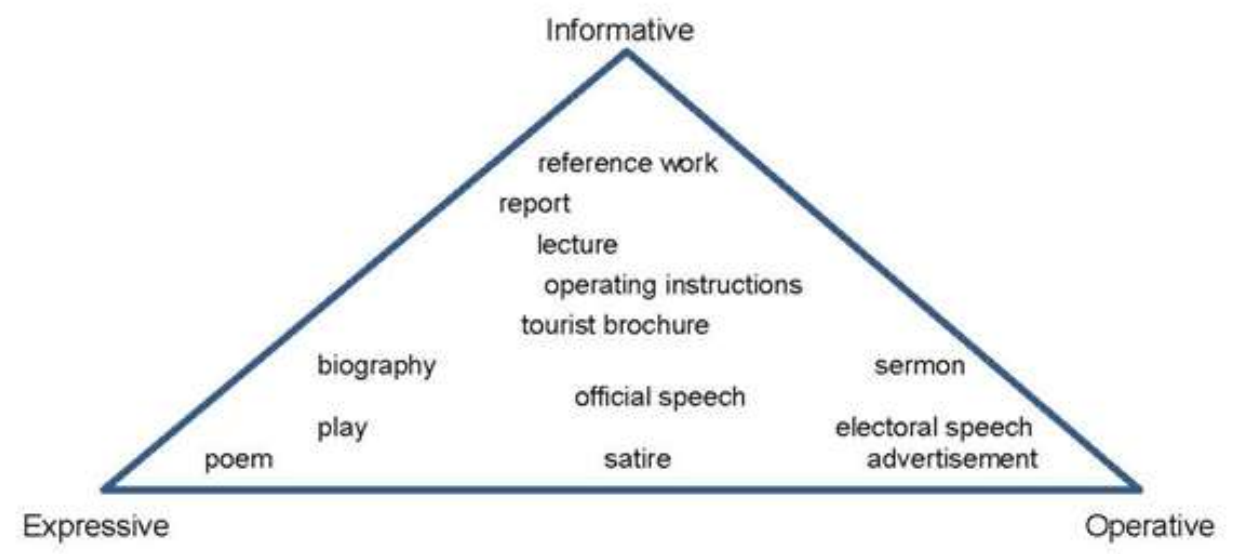

As see in the above diagramme, advertisement is a typical operative text type. According to the functional characteristics of text types and links to translation methods (Reiss, 1971), the language function of operative text is appellative, which means to make an appeal to text receiver. Nord (2001) noted that, directed at the receiver's sensitivity or disposition to act, the appellative function is designed to induce the target readers to respond in a particular way. Nord then further divided the appellative function into three: direct appellative function, indirect appellative function and poetic appellative function. According to Nord (2006), direct indicators of the appellative function would be features like imperatives or questions or model verbs like must or should. Yet the function may also be achieved indirectly through linguistic or stylistic devices that point to a referential or expressive function, such as superlatives, adjectives or noun expressing positive values (like "completely natural"). Poetic appellative function operates in poetic language appealing to aesthetic sensitivity.

\subsection{Three Beauty Theory}

The theory of the Three Beauty was first proposed by Lu Xun (1881-1936), a leading figure of modern Chinese literature, in his lecture notes A Concise Outline of Chinese Literary History in 1926. It was then adapted by Xu Yuanchong (1921-) into the translation of Chinese poem. Xu Yuanchong is a Chinese translator who had translated over 3000 classic Chinese poems into English and French. The Three Beauty, according to Lu Xun, includes the beauty in form, sound and sense: "firstly the beauty of meaning, is to be sensed by heart; secondly the beauty of sound, is to be sensed by ears; thirdly the beauty of form, is to be sensed by eyes" (Lu Xun, 1981). Xu adopted this theory into the translation of poem, in order to present the beauty of the source text in the above-mentioned aspects in the target text. The Three Beauty Theory originated from the traditional Chinese translation theory, though it surmounts the traditional principle of "fidelity". It has become a developed, rich and consummate theory in the theory of poem translation nowadays. The Three Beauty refers to the beauty of language in three aspects, namely meaning, sound and form. "Meaning" refers to the explicit and implicit meaning of words, phrases and sentences in the text which are normally implied in the cultural and linguistic aspects. (Yang Ying, 2011) "Sound" refers to the tone, rhythm and melody of the lines or text. "Form", on the other hand, means the length of the sentence, the parallelism in structure, etc. In the light of $\mathrm{Xu}$, "meaning" is the most important aspect among the three, followed by "sound" and "form". On the other hand, in fact, focus given to the beauty of sound in Chinese text, particularly poem, proverb, public notice, advertisement, etc. is very much more if compared to other aspects and other languages. Every Chinese Character is monosyllabic and tonic, which makes Chinese a natural poetic language (Zhaohui Yan, 2013). The phonological beauty of the Chinese text makes it readable and memorable.

\section{Previous Studies}

A survey of previous studies shows that there are quite a number of publications of studies and research on advertisement translation, the Functionalist Theory and the Three Beauty Theory. Tan Yizhi (2008) in his research in ads translation from the perspective of functionalist theory, noted that due to cultural differences between English and Chinese, the appropriate changes of language forms and cultural information should be carried out during ads translation to realize original informative and persuasive functions. Li Xi (2011) noted that advertisement translation has its own regular pattern. His research mainly studies the strategies and criteria of advertisement translation based on the functionalist translation theory. It is suggested that target language style, reader's reaction and target language culture have to be taken into account in doing advertisement translation. Yang Ying (2011) pointed out that, as an aesthetic practice, the translation of Chinese lyrics prose should convey all levels of aesthetic properties. The beauty in meaning, sound and form between the original and the translation version should be unified. According to Yang, a desirable version ought to successfully reproduce the original beauty in meaning, form and sound so as to bring the TL readers the same aesthetic experience as can be felt by the SL readers. Puteri Roslina, Wan Halizawati and Anis Shahirah (2013) in their study on translation of theme in cosmetic product advertisements, pointed out that translation strategies applied by the translator are basically literal translation. They proposed that the translator should take into 
account the readers, the image of the company, as well as the language factor in doing advertisement translation. Wu Li-li (2013) employed Xu's the Three Beauty Theory in the translation of cosmetic brands. In the light of Wu, the Three Beauty Theory has very significant function and effect in the translation of cosmetic brands. Xiong Jun (2013) noted that the Functionalist approaches are more practical and effective in directing public sign translation. Chen Xi (2013) remarked that in the Chinese-English translation of poetic public notices, poetic forms are usually lost, but the key information are transmitted with adaptive translation method to realize the equivalent appellative function.

\section{Research Questions and Research Methodology}

From the survey of previous studies, it is found that the Chinese translation of English advertisement in a multiracial, multicultural and multilingual country like Malaysia has not received adequate attention from researchers. Apart from this, it is found that the adoption of Three Beauty Theory into the translation of advertisement has not captured much attention from researchers. Thus, this study attempts to fill this gap by looking into Chinese translation of English advertisement in Malaysian newspapers, based on the Functional Translation Theories and the Three Beauty Theory. From the perspective of functionalists, it is known that advertisement is categorised as operative text, and the language function is appellative function. Thus, it is crucial to find out how is a Chinese translated advertisement headline identified in terms of its appellativeness? And how to realize the equivalent appellative function in the Chinese translation of English advertisement?

Nord noted that, the appellative function is designed to induce the target readers to respond in a particular way, which is in the case of advertising, to market the products to the readers. In order to induce the target readers to have interest and more ideally, to buy the products, the translated headline has to be well received by the target readers. The appellative function is receiver-oriented. While the source text normally appeals to a source text reader's susceptibility and experience, the appellative function of a translation is bound to have a different target. It means that the appellative function will not work without the receiver's cooperation (Chen Xi, 2013). It is known that the receivers' (the Chinese readers, in this context) love for the beauty of its language, especially phonological beauty is much deeper if compared to the readers of other languages. Due to the receivers (the Chinese readers, in this context) aesthetic and their passion for the beauty of language, the appellativeness of the translation will be discussed, based on the Three Beauty Theory in this paper. This research attempts, firstly, to analyse the appellativeness of the Chinese translated advertisement headline, and secondly, to improve the appellativeness of the headlines based on the Three Beauty Theory.

This study employs a qualitative study. Data was collected from printed advertisements in English and Chinese newspapers in Malaysia. Advertisements available in the two languages were filtered out from the advertisements collected from the English and Chinese newspapers. The original text (English advertisements) were basically collected from The Star and The New Straits Times, while the translated Chinese advertisements were from Sin Chew Daily and Chinese Press, published from $4^{\text {th }}$ to $17^{\text {th }}$ August 2014. There were altogether 31 English and Chinese advertisements collected within the two weeks.

Generally the advertisement text consists of headline, slogan, caption and information like telephone number, address, website and so on. In the data collection in this research, focus will be given to the headline. Advertisements with purely informative headlines, for example, "Parkson Extreme Warehouse Sale", "UTAR Open Day", etc will be eliminated. Headlines which are perceived to be persuasive and creative, like "Trends Change. Style Remains.", "In Time. In Style. Inspired." will be collected for data analysis. The selected translated headlines will then be analyzed, from the perspective of the Three Beauty Theory. The appellativeness of the headlines will be identified based on the effectiveness of its meaning, form and sound. Next, the less appellative and not-appellative headlines will be further refined, in terms of its meaning, sound and form. The headlines collected for analysis are as below (arranged according to alphabetical order):

Table 1. The English headlines (ST) and Chinese headlines (TT), and types of product/service of the advertisement

\begin{tabular}{lllc}
\hline No. & English Headline (ST) & Chinese Headline (TT) & Product/Service \\
\hline 1 & Built to further performance & 驾驭高性能 & Tyres \\
2 & Come and get it now & 千载难逢, 愉悦无穷 & Automotive \\
3 & Delicious new value! & 享受超值价格, 享受全新选择 & Fast food \\
4 & I need a fuel that fits my tight budget & 我所需要的燃油必须能符合我的 & Petrol \\
& & 紧绷预算 & Insurance \\
5 & It is nice to know you are protected 很高兴您可受保至85岁 & Automotive \\
6 & up to 85 years old & & Department \\
7 & Merdeka! Buy a car! & Merdeka! 买新车啦！ & Automotive \\
8 & More great specials! & 更多选择更多优惠！ & Bank \\
9 & Prizes, prizes, prizes! & 您的最佳搭配 & Bank \\
\hline
\end{tabular}


The data was analysed, based on the effectiveness of meaning $(\mathrm{M})$, form $(\mathrm{F})$, and sound $(\mathrm{S})$. The data will then be categorized into three (Appellative Translation, Less Appellative Translation \& Not-appellative Translation), according to their effectiveness of appellative function. Data which are found less or not appealing will then be further refined and polished, based on the Three Beauty Theory.

Table 2. The effectiveness of the Chinese translation in terms of meaning, form and sound

\begin{tabular}{|c|c|c|c|c|c|}
\hline \multirow[t]{2}{*}{ No. } & \multirow[t]{2}{*}{ English Headline (ST) } & \multirow[t]{2}{*}{ Chinese Headline (TT) } & \multicolumn{3}{|c|}{ Three Beauty Theory } \\
\hline & & & M & $\mathrm{F}$ & $\mathrm{S}$ \\
\hline 1 & Built to further performance & 驾驭高性能 & & & \\
\hline 2 & Come and get it now & 千载难逢, 愉悦无穷 & & $\sqrt{ }$ & $\sqrt{ }$ \\
\hline 3 & Delicious new value! & $\begin{array}{l}\text { 享受超值价格, } \\
\text { 享受全新选择 }\end{array}$ & $\sqrt{ }$ & $\sqrt{ }$ & $\sqrt{ }$ \\
\hline 4 & $\begin{array}{l}\text { I need a fuel that fits my tight } \\
\text { budget }\end{array}$ & $\begin{array}{l}\text { 我所需要的燃油 } \\
\text { 必须能符合我的紧绷预算 }\end{array}$ & & & \\
\hline 5 & $\begin{array}{l}\text { It is nice to know you are } \\
\text { protected up to } 85 \text { years old }\end{array}$ & 很高兴您可受保至85岁 & & & \\
\hline 6 & Merdeka! Buy a car! & Merdeka！买新车啦！ & $\sqrt{ }$ & $\sqrt{ }$ & $\sqrt{ }$ \\
\hline 7 & More great specials! & 更多选择更多优惠！ & $\sqrt{ }$ & $\sqrt{ }$ & $\sqrt{ }$ \\
\hline 8 & Perfect fit for you! & 您的最佳搭配 & $\sqrt{ }$ & & \\
\hline 9 & Prizes, prizes, prizes! & 数不尽的奖品等着您 & $\sqrt{ }$ & & \\
\hline 10 & Trends change. Styled remain. & $\begin{array}{l}\text { 将梦想化为现实， } \\
\text { 即刻行动吧！ }\end{array}$ & $\sqrt{ }$ & & \\
\hline
\end{tabular}

$\mathrm{M}=$ meaning, $\mathrm{F}=$ form, $\mathrm{S}=$ sound

\subsection{Appellative Translation}

Table 3. Chinese headlines (TT) which are considered appellative, based on its effectiveness of translation, in terms of meaning, sound and form

\begin{tabular}{llll}
\hline No. & $\begin{array}{l}\text { English Headline (ST) \& } \\
\text { Its Effectiveness of M,F,S }\end{array}$ & $\begin{array}{l}\text { Chinese Headline (TT) \& } \\
\text { Pronunciation Scheme }\end{array}$ & $\begin{array}{l}\text { Literal meaning of TT } \\
\text { in English }\end{array}$ \\
\hline 3 & $\begin{array}{l}\text { Delicious new value! } \\
\text { (MFS) }\end{array}$ & 享受超值价格 , 享受全新选择 & $\begin{array}{l}\text { Enjoy the premium price, } \\
\text { enjoy the new options }\end{array}$ \\
6 & $\begin{array}{l}\text { Merdeka! Buy a car! } \\
\text { (MFS) }\end{array}$ & Merdeka ! 买新车啦 ! & Free (independent)! Buy a \\
& $\begin{array}{l}\text { More great specials! } \\
\text { (MFS) }\end{array}$ & 更多选择更多优惠 ! & More choices, more \\
\end{tabular}

$\mathrm{M}=$ meaning, $\mathrm{F}=$ form, $\mathrm{S}=$ sound

The TTs in Table 3 had successfully represented the content of the STs, in terms of meaning, sound and form. Firstly, in terms of meaning, the words, phrases used in the TTs are proper, short and sweet. TT3, TT6 and TT7 have perfectly retained the conceptual meaning of their STs. As for TT6, the word "Merdeka" (a Malay word, meaning "free" or "independent". Malaysia National Day is also called Independent Day, it is the day the country freed from the British Colonial governance) retained in the TT, has created a sense of belonging to Malaysian.

Secondly, in terms of sound, there are rhymes and alliteration/repetition in the translation. The word “格” [ky] rhymes with “择” [tsy] in TT3, whereas in TT5: "ka” [kA] in the word "Merdeka" rhymes with “啦” [la]. There are repetitions of the lexicons in TT3 (享受) and TT7 (更多). The rhymes and alliteration created phonic aesthetic feelings to the receivers.

In terms of form, TT3 and TT7 are perfectly parallel, and TT6 is almost parallel in structure. The six-six Chinese character and syllabus (享-受-超-级-价-值, 享-受-全-新-选-择) in TT3 and four-four Chinese character and syllabus (更-多-选-择, 更-多-优-惠) in TT7 makes the TTs sound poetic, beautiful and attractive to Chinese readers. Apart from that, TT3 and TT6 are parallel not only in terms of number of character and syllabus in each line, but also in terms of their part of speech. As for TT3, they are verb + modifier + object (享受+超值+价格, 享受+全新+选择), whereas for TT7, they are modifier + noun (更多+选择, 更多+优惠).

From the above discussion, it can be seen that TT3, 6 and 7 are effective in terms of meaning (M), form (F) and sound (S). In summary, TT3, TT6 and TT7 are appellative. 
5.2 Less Appellative Translation

Table 4. Chinese headlines (TT) which are considered less appellative, based on its effectiveness of translation, in terms of meaning, sound and form

\begin{tabular}{llll}
\hline No. & $\begin{array}{l}\text { English Headline (ST) \& } \\
\text { Its Effectiveness of M,F,S }\end{array}$ & Chinese Headline (TT) & $\begin{array}{l}\text { Literal meaning of TT } \\
\text { in English }\end{array}$ \\
\hline 2 & $\begin{array}{l}\text { Come and get it now } \\
\text { (FS) }\end{array}$ & 千载难逢 , 愉悦无穷 & $\begin{array}{l}\text { Once in a blue moon } \\
\text { The pleasure is endless } \\
\text { Your best match! }\end{array}$ \\
& $\begin{array}{l}\text { Perfect fit for you! } \\
\text { (M) }\end{array}$ & 您的最佳搭配 & Young \\
9 & $\begin{array}{l}\text { Prizes, prizes, prizes! } \\
\text { (M) }\end{array}$ & 数不尽的奖品等着您 & $\begin{array}{l}\text { Countless prizes are waiting } \\
\text { for you! }\end{array}$ \\
& $\begin{array}{l}\text { See it comes to life, why wait? } \\
\text { (M) }\end{array}$ & 将梦想化为现实, 即刻行动吧 ! & $\begin{array}{l}\text { Realize the dreams, } \\
\text { take actions immediately! }\end{array}$ \\
\hline
\end{tabular}

$\mathrm{M}=$ meaning, $\mathrm{F}=$ form, $\mathrm{S}=$ sound

From Table 4, it can be seen that TT2 is effective in terms of form and sound, whereas TT8, TT9 and TT10 are effective in terms of meaning.

TT2's four-four character and syllabus structure, parallelism and rhymes make it attractive and beautiful in terms of its form and sound. Nevertheless, TT2 fails to render the conceptual meaning of its ST. ST2 "Come and get it now" was translated to “千载难逢, 愉悦无穷” (Once in a blue moon, the pleasure is endless), the sense of urge (get it now) is retained in TT2, but another message, "get it", which is the core of the content (buy it) is not rendered into TT2. In addition to that, over translation has been done, where the translator added information "the pleasure is endless" which is of no value added to TT2. The aspect of "meaning" in TT2 has to be refined. It is suggested that "Come and get it now” is translated to “今天就让宝马成为您的座驾” (Let BMW becomes your personal car today). The Chinese translated name of the brand of the product “宝马” is mentioned in the translation. “宝马” literally means “Treasurous Horse", is very culturally rich in Chinese. Adaptive translation approach has been applied, and the sense of urge (let it becomes your car today) has been created in the translation. In terms of form, it is parallel (six-six structure); in terms of sound, “马”[mA] rhymes with l驾” [ tcia].

TT8, TT9 and TT10 have successfully rendered the conceptual meaning of their STs. The information in STs are well retained in the TTs. Adaptive translation approach was applied in the Chinese translation of ST8, 9 and 10. As for ST8, "perfect fit" has been translated to “搭配” , which means "best match". "Prizes, prizes, prizes!" in ST9 has been translated to “数不尽的奖品” (countless prizes), while for "comes to life" and "why wait" in TT10 has been translated to “将梦想化为现实” (realize the dreams) and “即刻行动” (take actions immediately). The lexicons used in TT8, TT9 and TT10 are effective, in terms of meaning, but the TTs can be further crafted so that they are more beautiful in terms of sound and form. The proposed headline for sample (8) “您与HINO天作之合” (You and HINO are of natural fit) is a four-four character and syllabus structure, where “您与HINO” is parallel with “天作之合”, and “NO” [no] rhymes with “合” [xy]. The parallelism and rhymes make it beautiful, in terms of form and sound. In terms of meaning, "perfect fit" has been translated to a Chinese idiom, “天作之合” (natural fit, literally means a couple matched by the God), is a better cultural icon for the receivers, as noted by Tan Yizhi (2008) "cultural information should be carried out during ads translation to realize original informative and persuasive functions".

As for TT9, the modifier of the object, prizes “数不尽的” (which means "countless") is too lengthy, making the TT less attractive in terms of sound. It is suggested that “数不尽的” is replaced with “更多更多” (meaning “more and more”), making the headline a six-three structured sentence (更多更多奖品 - 等着您), creating an effect of alliteration (the repetition of 更多). In addition to that, the rhymes of “品” [ $\left.\mathrm{p}^{\mathrm{h}} \mathrm{in}\right]$ and “您” [nin], has created a phonic aesthetic feeling to the receivers.

TT10 is less effective in terms of form and sound. The seven-five structure sentence makes it not readable and not memorable. The proposed translation is “别等了让CiTi Bank 帮你实现梦想” (Don’t wait- Let CiTi Bank helps you to realize your dreams). In terms of form, “计CiTi Bank” is almost parallel with “帮你实现梦想”. In terms of sound, "bank” [næyk] almost rhymes with “想”. [6iay]

TT2, TT8, TT9 and TT10 had been refined and the proposed translation were made based on Three Beauty Theory, where the TTs had been further refined and polished, in terms of their meaning, form and/or sound.

5.3 Not-appellative Translation

Table 5. Chinese headlines (TT) which are considered not-appellative, based on its effectiveness of translation, in terms of meaning, sound and form.
No. English Headline (ST) \&
Chinese Headline (TT) \&
Its Effectiveness of M,F,S
Pronunciation Scheme
Literal meaning of TT
in English

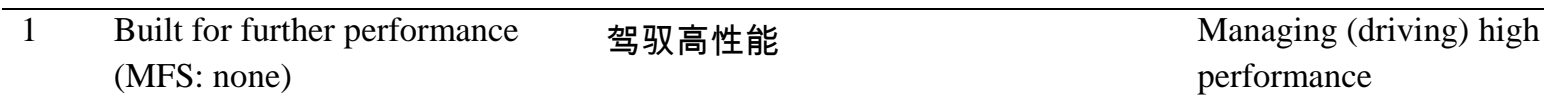


4 I need a fuel that fits my tight budget(MFS: none)

It is nice to know that you are protected up to 85 years old

(MFS: none)
我所需要的燃油必须能符合我的 紧绷预算

很高兴您可受保至85岁
The fuel I need must be able to meet my tight budget

(I am) very happy you can

be insured up to 85 years

old

$\mathrm{M}=$ meaning, $\mathrm{F}=$ form, $\mathrm{S}=$ sound

It can be seen that, the TTs in Table 5 are not effective in terms of meaning, form and sound. Literal translation and word-by-word translation approach had been applied in the above translation. ST1: Buit-驾驭; further performance高性能. ST4: I -我, need-需要, a fuel-燃油, fits- 能符合, my-我的, tight-紧朋,budget-预算.ST5: ST4: nice-很高兴, you-您, are protected-可受保, up to- 至; 85 years old-85岁. TT1, 4 and 5 are effective in transmitting the information in their STs, but the language used is less natural, sounds English, and not appealing. As noted by Tan Yizhi (2008), the appropriate changes of language forms should be carried out during ads translation to realize original informative and persuasive functions.

TT1: The word “高性能” (high performance) should be used as a noun modifier in Chinese language, but not as an object in this context. A four-four structure (parallel) headline is suggested for ST1 “驾驭前程突破极限”, which means "Managing future | Breaking through limitation". The word “驾驭” used in TT1 is remained as it is very well transmitting the conceptual meaning of the ST, "Built for further performance". "For further performance" is retranslated as "managing the journey ahead" and "breaking through limitation". The explicit meaning carried out is to control the engine, to speed up and to break through the limitation, while the implicit meaning is to manage the future, to perform better and to break through the limitation in the life. The lexicon “前程”, which means "the journey ahead" originally, has been extended to the meaning "future" in the Chinese lexicology. Adaptive translation approach applied in the translation has lighten up the headline, and presenting the implicit and explicit meaning of the ST. In addition to

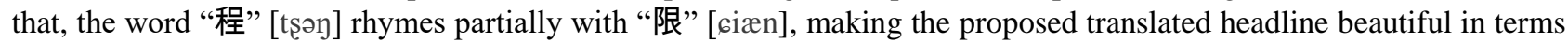
of meaning, form and sound.

TT4: It is suggested that TT4 is further refined in terms of meaning, form and sound, making it a six-six character and syllabus structure headline, to create an effect of parallelism: “何必为了燃油-束紧您的腰带?”紧(Why tighten your belt for fuel?). Adaptive translation approach, as well as some changes of cultural information has been carried out in this translation. "Tighten your belt" means to reduce the expenses due to financial constraint, has its cultural information in Chinese language. In addition, a declarative sentence is turned to a interrogative sentence, making the headline more appealing to the receivers.

TT5: Changes of language form has to be carried out so that it is more natural and appealing to the receivers. Other than that, the language has to be polished, in terms of meaning, form and sound. It is proposed that ST5 is translated to “不得不信的事实-您可受保至85岁！”(A fact that cannot find belief in: You are insured up to 85 years old!). The change of language form has been carried out in the translation, where Double Negative Sentence (cannot be not) has been created. Double Negative Sentence is commonly used in the Chinese language to cancel one another to produce affirmative. In the context of TT5, it is to affirm that "it is a fact that you have to believe". In terms of form, “不得不信的事实” is almost parallel with “您可受保至85岁” (eighty five is pronounced as “bā shí wǔn”, with very short “shí"). In terms of sound, “实”[si] almost rhymes with “岁” [suei].

In summary, the above TTs have been refined and polished, in terms of their meaning, sound and form, making the proposed translated headlines more linguistically beautiful and more appealing to the receivers.

\section{Findings and Conclusions}

According to the functionalist perspective, advertisement is categorised as operative text, and the language function is appellative function. According to Nord (2006), function or functionality is not a quality of a text in itself but one that is attributed to the text by the receiver in the moment of reception. Thus, it is the receiver who decides whether (and how) a text "functions". It is known that the Chinese readers' (the receivers, in this context) love for the beauty of its language, especially in terms of sound is much deeper if compared to the readers of other languages, due to Chinese language feature. Therefore, the appellativeness of the Chinese translation of English advertisement headlines, in this paper is analysed and identified, based on Three Beauty Theory.

From the above analysis and discussion, it is found that the use of three aspects of Chinese language (meaning, sound and form) in analysing and identifying the appellativeness of a Chinese translated English headline is appropriate. In addition to that, the effectiveness of the Chinese translation of English advertisement headline, in terms of meaning, sound and form could be analysed and improved, based on the Three Beauty Theory. In short, Functional Translation Theories provides a guideline on the purpose of translation, typolology, language function and translation strategy in the Chinese translation of English advertisement. On the other hand, the Three Beauty Theory safeguards the effectiveness and the beauty of Chinese language, in terms of meaning (idea, message), form (structure) and sound (phonology). The Chinese translation of English (or perhaps, including other languages) advertisement needs a theory derived from its language and literature, Three Beauty Theory, for example to direct its use and application of the language.

In addition to that, it is very much agreed that "due to cultural differences between English and Chinese, the appropriate changes of language forms and cultural information should be carried out during ads translation to realize original informative and persuasive functions", as quoted by Tan Yizhi (2008). Last but not least, it is hoped that this research will inspire more studies on the application of Functional Translation Theory and Three Beauty Theory in the Chinese 
translation of English advertisement, specifically the Chinese receivers' perceptions towards the Chinese translation of English advertisement headlines.

\section{References}

Bühlur, K.(1934) .Sprach theorie: Die Darstellungs funktion der Sprache. Stuttgart: Custav Fischer.

Bolen, W. H. (1984). Advertising. (2nded.). New York: John Wiley \& Sons.

Chen X. (2013). Teaching English Translation of Chinese Poetic Public Notices. Proceeding of The 14 ${ }^{\text {th }}$ International Conference on Translation. $7^{\text {th }}$ Asian Translators' Forum.280-293.

Munday, J. (2010). Introducing Translation Studies: Theories and Applications. Shanghai: Shanghai Foreign Language Education Press.

Nord, Ch. (1997). Defining Translation Functions. The Translation Brief as a Guideline for the Trainee Translator. Ilha Do Desterro. n33 1997. 41-55. [Online] Available: https://periodicos.ufsc.br/index.php/desterro/article/view/9208/9484 (July 1, 2016)

Nord, CH. (2001). Dealing with Purposes in Intercultural Communication: Some Methodological Considerations. $\begin{array}{lllllll}\text { Revista Alicantina } & \text { de } & \text { Estudios } & \text { Ingleses } & 151-166 .\end{array}$ Available:https://rua.ua.es/dspace/bitstream/10045/5290/1/RAEI_14_10.pdf (July 1, 2016)

Nord, CH. (2006). Translating as a Purposeful Activity: A Perspective Approach. TEFLIN Journal, Vol 17, No. 2. 131143. [Online] Available:http://journal.teflin.org/index.php/journal/article/view/65/254 (July 1, 2016)

Puteri R. A. W., Wan H. W. M., Anis Sh. A. S. (2013). Analisis Penterjemahan TajukUtama Iklan Barangan AVON. Proceeding of The $14^{\text {th }}$ International Conference on Translation. $7^{\text {th }}$ Asian Translators ' Forum.421-435.

Reiss, K. (1971/2000).Translation Criticism: The Potentials and Limitations: Categories and Criteria for Translation Quality Assessment. (translated by Erroll, F. R.). Manchester: St Jerome Publishing.

Xiong J. (2013). Functionalist Approaches to English Translation of Chinese Public Signs. Proceeding of The 14 International Conference on Translation. $7^{\text {th }}$ Asian Translators' Forum.706-722.

Yang Y. (2011). On The Representation of Three Beauty's in the Translation of Chinese Lyric Prose. Journal of Studies in Literature and Language. Vol.2.No. 1.96-102.Zhaohui Yan. (2013). The Creative Reproduction of Chinese Ancient Poetry's Phonological Beauty in English Translation. Theory and Practice in Language Studies. Vol. 3, No. 5. 846-851. [Online] Available: http://www.academypublication.com/issues/past/tpls/vol03/05/19.pdf (February 2, 2016)

(Li Xi). 李希. (2011). 《功能翻译理论下的广告翻译研究》. 信阳师范学院硕士论文.

(Lu Xun). 鲁迅.(1981).《鲁迅全集》. 北京：人民文学出版社.

(Tan Yizhi). 谭逸之. (2008). 《功能翻译理论视野下的广告翻译研究》.[Online] Available: http://www.mianfeiwendang.com/doc/ce0b65ab23f8974471d14e10 (December 10, 2015)

(Wu Li-li). 吴丽丽.(2013). 从许渊冲“三美”原则论化妆品品牌的翻译.《海外英语》2013年第8期. 